\title{
Radix Entomolaris in Mandibular First Molars: Report of 3 Cases
}

\author{
Radix Entomolaris em Primeiros Molares Mandibulares: Relato de 3 Casos \\ Radix Entomolaris en primeros molares mandibulares: Reporte de 3 Casos
}

Received: 11/02/2021 | Reviewed: 11/09/2021 | Accept: 11/15/2021| Published: 11/24/2021

\author{
André Luiz da Costa Michelotto \\ ORCID: https://orcid.org/0000-0001-7855-4407 \\ Federal University of Paraná, Brazil \\ E-mail: andremichelotto@hotmail.com \\ Bruno Cavalini Cavenago \\ ORCID: https://orcid.org/0000-0003-3203-0899 \\ Federal University of Paraná, Brazil \\ E-mail: brunocavenago@hotmail.com \\ Stephanie Tiemi Kian Oshiro \\ ORCID: https://orcid.org/0000-0002-3515-3715 \\ Cruzeiro do Sul University, Brazil \\ E-mail: steoshiro@gmail.com \\ Ângela Toshie Araki Yamamoto \\ ORCID: https://orcid.org/0000-0003-4402-7531 \\ Cruzeiro do Sul University, Brazil \\ E-mail: angela.araki@cruzeirodosul.edu.br \\ Antonio Batista \\ ORCID: https://orcid.org/0000-0002-6571-6662 \\ Federal University of Paraná, Brazil \\ E-mail: endobatista@gmail.com
}

\begin{abstract}
The radix entomolaris is an anatomical variation characterized by the presence of an additional root located in the distal-lingual region of mandibular molars. An accurate diagnosis is necessary to plan and institute effective endodontic therapy for teeth with this condition. The aim of this report was to present three cases of endodontic management in permanent mandibular first molars with radix entomolaris using contemporary technical resources. For diagnosis, periapical radiographs indicated the possibility of morphological alterations, which were confirmed in two cases by cone beam computed tomography (CBCT). Ultrasonic tips and magnification with operative microscopy were the auxiliary resources used for locating the root canals, which were prepared with NiTi rotary instrument systems and filled with gutta-percha by using the lateral condensation technique and AH Plus sealer. Resources such as periapical radiography, $\mathrm{CBCT}$, magnification with operative microscopy, ultrasonic devices and NiTi instruments can be extremely valuable for use in the diagnosis and clinical approach to endodontic treatment of mandibular first molars with radix entomolaris.
\end{abstract}

Keywords: Cone-beam computed tomography; Endodontics; Molar; Root canal preparation; Root canal treatment; Tooth abnormalities.

\section{Resumo}

O radix entomolaris é uma variação anatômica caracterizada pela presença de uma raiz adicional localizada na região distal-lingual dos molares inferiores. Um diagnóstico preciso é necessário para planejar e instituir uma terapia endodôntica eficaz para dentes com essa condição. O objetivo deste relato foi apresentar três casos de tratamento endodôntico em primeiros molares inferiores permanentes com radix entomolaris utilizando recursos técnicos contemporâneos. Para o diagnóstico, as radiografias periapicais indicaram a possibilidade de alterações morfológicas, que foram confirmadas em dois casos por tomografia computadorizada de feixe cônico (TCFC). Pontas ultrassônicas e magnificação com microscopia operatória foram os recursos auxiliares utilizados na localização dos canais radiculares, os quais foram preparados com sistemas de instrumentos rotatórios de NiTi e preenchidos com gutapercha pela técnica de condensação lateral e cimento AH Plus. Recursos como radiografia periapical, TCFC, aumento com microscopia operatória, dispositivos ultrassônicos e instrumentos NiTi podem ser extremamente valiosos para uso no diagnóstico e abordagem clínica para tratamento endodôntico de primeiros molares inferiores com radix entomolaris.

Palavras-chave: Tomografia computadorizada de feixe cônico; Endodontia; Molar; Preparo do canal radicular; Tratamento do canal radicular; Anormalidades dentárias. 


\section{Resumen}

El radix entomolaris es una variación anatómica caracterizada por la presencia de una raíz adicional ubicada en la región distal-lingual de los molares mandibulares. Es necesario un diagnóstico preciso para planificar e instituir una terapia endodóntica eficaz para los dientes con esta afección. El objetivo de este informe fue presentar tres casos de manejo endodóntico en primeros molares mandibulares permanentes con radix entomolaris utilizando recursos técnicos contemporáneos. Para el diagnóstico, las radiografías periapicales indicaron la posibilidad de alteraciones morfológicas, las cuales fueron confirmadas en dos casos mediante tomografía computarizada de haz cónico (CBCT). Las puntas ultrasónicas y el aumento con microscopía operatoria fueron los recursos auxiliares utilizados para la localización de los conductos radiculares, que se prepararon con sistemas de instrumentos rotativos NiTi y se rellenaron con gutapercha mediante la técnica de condensación lateral y sellador AH Plus. Recursos como radiografía periapical, CBCT, aumento con microscopía operatoria, dispositivos ultrasónicos e instrumentos de NiTi pueden ser extremadamente valiosos para su uso en el diagnóstico y abordaje clínico del tratamiento endodóntico de los primeros molares mandibulares con radix entomolaris.

Palabras clave: Tomografía computarizada de haz cónico; Endodoncia; Molar; Preparación del conducto radicular; Tratamiento del conducto radicular; Anormalidades de los dientes.

\section{Introduction}

Knowledge of the internal anatomy and possible variations in the morphology of the root canal system is essential for performing successful endodontic therapy. Professionals must be prepared to identify and perform endodontic treatment of teeth that exhibit unusual configurations, to ensure that the entire root canal system will be debrided and filled.

Among the dental groups that may have variations are the permanent mandibular molars, however, in Caucasian populations, these teeth are generally two rooted (one mesial root with two mesial root canals, and one distal root with one distal root canal) [Vertucci et al. 1984]. The presence of a supernumerary root in the distal-lingual region of first permanent mandibular molars was first described by Carabelli, who called it the radix entomolaris (RE). The prevalence of RE differs significantly depending on the ethnic group, ranging from 0 to 33.33\% [Garg et al. 2010, Tu, 2009]. The high prevalence in Asian populations such as Chinese, Korean and Taiwanese individuals with an occurrence ranging from $24.5 \%$ to $33.3 \%$ [Tu et al. 2009, Kim, 2018], has led to this morphology being considered normal (eumorphic root morphology) [Kim et al. 2018]. In African, Eurasian, Caucasian, and Indian populations, this is considered dysmorphic root morphology, with a low prevalence of $<5 \%$ [Calberson et al. 2007]. In Black populations, the maximum frequency found has been 3\% [Sperber et al. 1998], while in Caucasians, the radix entomolaris is uncommon with maximum occurrence from 3.4 to 6.8\% [Ferraz et al. 1993, De Moor, 2004].

Radix entomolaris can be found in first, second and third mandibular molar teeth [Song et al. 2010, Ferraz, 1993], however, the literature has reported a higher number of occurrences in case reports of first molars [Calberson et al. 2007, Rozito,2014, Abella, 2011].

Regarding the clinical management of these root canals, the literature reports the importance of resources such as computed tomography for diagnosis [Abella et al. 2011, Rofrigues,2016], microscopic magnification [Calberson et al. 2007] and the use of ultrasonic inserts [López-Rosales et al. 2015] to help with localization. In addition, preparation with automated Niti systems is indicated, mainly due to the curvatures that may be present these root canals [Abella et al. 2011, LópezRosales,2015].

In view of this foregoing, it is important for clinicians to be able to diagnose and perform endodontic treatment in a safe and predictable manner. Therefore, the aim of this report was to present the diagnosis and endodontic management of three clinical cases of permanent mandibular first molars with radix entomolaris with the use of contemporary technical resources.

\section{Methodology}

The present study refers to a clinical case report, a descriptive study. The search performed in Pubmed and Scielo 
databases and consists of a qualitative research. The study complied with the ethical principles of the Declaration of Helsinki and signed the Informed Consent Form (FICF) by the person responsible.

\section{Case reports}

\section{Case 1}

The patient, an 85-year-old Asian woman, was referred to the private practice for endodontic treatment of tooth 36 , as she had already consulted another professional, who had been unable to locate the root canals. Upon clinical examination, the tooth was asymptomatic and had extensive loss of coronal structure. In the radiographic examination, the tooth showed no periapical alteration, but had atresic canals and an aspect suggestive of a supplementary root, possibly a "radix" (Figure 1A). In the first appointment, an inferior alveolar nerve block followed by buccal infiltration was performed with epinephrine 1: 100 000 and with 2\% mepivacaine (DFL, Rio de Janeiro, Brazil). The coronal tissue loss prevented the absolute isolation clamp from being placed on the tooth to be treated, so the clamp was placed on tooth 37 and teeth 37, 36 and 35 were isolated (Figure 1B). The temporary filling was removed with a round high-speed diamond bur (1014, KG Sorensen, Cotia, Brazil). Under an operating microscope (16x magnification) (Alliance, São Carlos, Brazil) and using a pear diamond ultrasonic tip (E6D, Helse, São Paulo, Brazil), it was possible to locate the disto-vestibular (DB) and disto-lingual (DL) root canals (Figure 1B). The canals were negotiated with C-Pilot files \# 10 and \# 15 (VDW Dental, Munich, Germany). The location of the DL canal most displaced towards the lingual region characterized the presence of a "radix entomolaris" root. In order to verify the working lengths an electronic apex locator was used (Root ZX; J. Morita Inc., Japan). The canals were copiously irrigated with $2.5 \%$ sodium hypochlorite ( $8 \mathrm{~mL}$ per canal) and a final rinse with 17\% EDTA for $3 \mathrm{~min}$ was performed before drying the canals with matched paper points \# 30 (VDW Dental, Munich, Germany). An intracanal dressing with calcium hydroxide paste (UltraCal XS, Ultradent) was applied for 10 days. During the second visit, an operating microscope was also used, enabling the mesiolingual canal (ML) and the mesio-buccal canal (MB) to be located. The MB was almost completely closed, mineralized, and it was impossible to negotiate it. After negotiating the ML with C-Pilot files \# 10 and \# 15 (VDW Dental, Munich, Germany), the root canals were instrumented with a NiTi CM rotary system (Pro-T, MK Life, Porto Alegre, Brazil), with the DB and DL canals instrumented to F3 (30.09) and the MB to F2 (25.08). Irrigation was performed in the same way as in the first visit. After drying the canals with paper points \# 30 (VDW Dental, Munich, Germany), the canals were filled with gutta percha using the lateral condensation technique and AH Plus sealer (Dentsply, Konstanz, Germany) (Figure 1C). The patient was referred for prosthetic rehabilitation.

Figure 1 - (A) Initial radiograph. (B) Location of the DB and DL (Radix entomolaris). (C) Final radiograph.

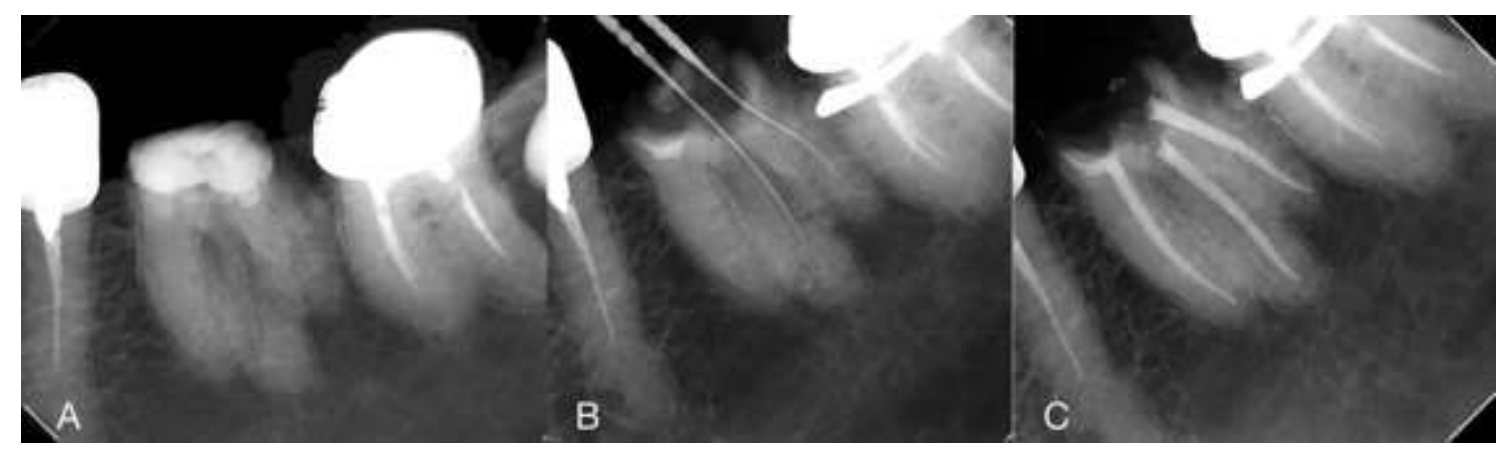

Source: Authors. 


\section{Case 2}

The patient, a 37-year-old Caucasian woman was referred for endodontic treatment of tooth 46, after an emergency appointment, due to symptomatic irreversible pulpitis. On clinical examination, the tooth was asymptomatic, and in the radiographic examination there was suggestion of the presence of a "radix" root between the mesial and distal roots (Figure 2A). During the first visit, an inferior alveolar nerve block followed by buccal infiltration was performed with epinephrine 1: 100000 and with 2\% mepivacaine (DFL, Rio de Janeiro, Brazil). The tooth was isolated with a rubber dam and the temporary filling was removed with a round high-speed diamond bur (1014, KG Sorensen, Cotia, Brazil). The mesial and distal-buccal canals were negotiated with C-Pilot \# 10 and \# 15 (VDW Dental, Munich, Germany). The MB and ML root canals were instrumented with a Reciproc Blue \# 25 (VDW Dental, Munich, Germany) and the DB was instrumented with two additional files, Mtwo \# 35.04 and \# 40.04 (VDW Dental, Munich, Germany). The canals were copiously irrigated with 2.5\% sodium hypochlorite $(8 \mathrm{~mL}$ per channel) and a final rinse with 17\% EDTA for 3 min was performed before drying the canals with matched paper points \# 30 (VDW Dental, Munich, Germany). An intracanal dressing with calcium hydroxide paste (UltraCal XS, Ultradent) was applied for 10 days. As the DL (Radix) root canal was not found, a CBCT (Prexion Elite, Tokyo, Japan) was requested. The scanning parameters were $90 \mathrm{KVp}, 5 \mathrm{~mA}$, a spatial resolution of $150 \square \mathrm{m}$ and a field of view of $50 \mathrm{x} 50 \mathrm{~mm}$. The tomographic image showed an extremely atresic canal, with intense dentin deposition in the cervical third, with no access to the root canal (Figure 2B). During the second visit, an operating microscope (16x magnification) and a pear diamond ultrasonic tip (E6D, Helse, São Paulo, Brazil), were used to remove dentin in the lingual direction, making it possible to locate the DL root canal ("Radix Entomolaris") (Figure 2C). After negotiation, instrumentation was performed with a Reciproc Blue \# 25 (VDW Dental, Munchen, Germany) and Mtwo \#35.04 (VDW Dental, Munich, Germany). The root canals were irrigated in the same way as in the first visit. After drying the canals with paper points \# 30 (VDW Dental, Munich, Germany), the root canals were filled with gutta-percha by using the lateral condensation technique and AH Plus cement (Dentsply, Konstanz, Germany) (Figure 2D) and the patient was referred for prosthetic rehabilitation.

Figure 2 - (A) Initial radiograph. (B) CBCT (C) Clinical image showing canal entrances after instrumentation (D) Final radiograph.

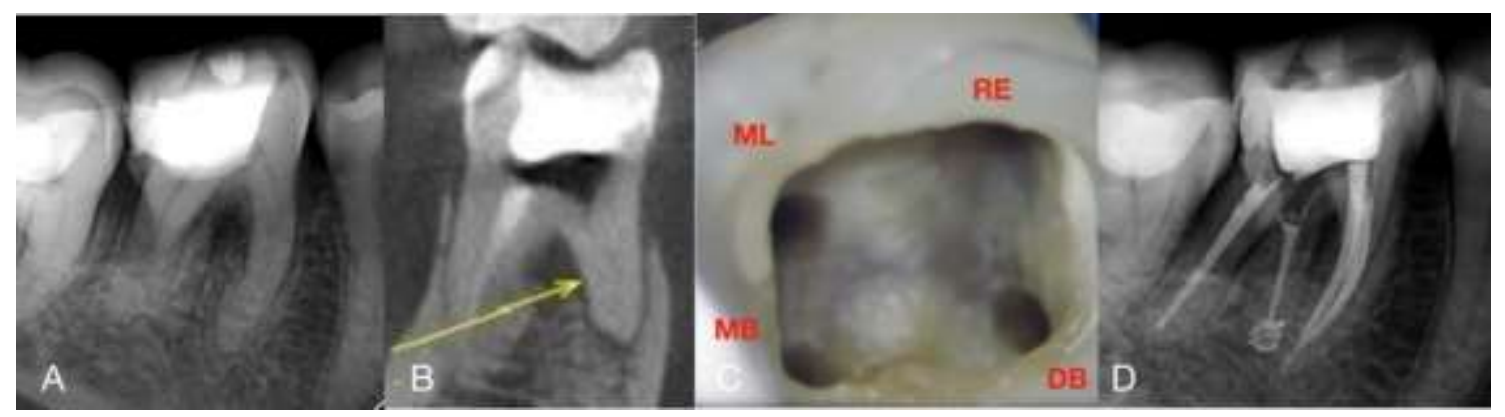

Source: Authors.

Case 3

A 36-year-old Caucasian man was referred for endodontic retreatment of tooth 46. In the anamnesis and clinical examination, the tooth was found to be asymptomatic and had extensive coronal destruction. Radiographic examination revealed the presence of apical periodontitis and unsatisfactory endodontic treatment (Figure 3A). The axial and coronal sections of the CBCT scan (Prexion Elite, Yoshida, Japan) showed evidence of the presence of a "radix entomolaris" root (Figures 3B and 3C). The scanning parameters were $90 \mathrm{KVp}, 5 \mathrm{~mA}$, a spatial resolution of $150 \square \mathrm{m}$ and a field of view of $50 \mathrm{x}$ $50 \mathrm{~mm}$. During the first visit, an inferior alveolar nerve block followed by buccal infiltration was performed with epinephrine 
1: 100000 and with 2\% mepivacaine (DFL, Rio de Janeiro, Brazil). The tooth was isolated with rubber dam and the decayed tissue was removed with a round high-speed diamond bur (1014, KG Sorensen, Cotia, Brazil). The filling material was removed from the mesial and disto-buccal root canals with the aid of an orange oil solvent (Biodinâmica, Ibiporã, Brazil) and C-Pilot \# 10 (VDW Dental, Munich, Germany). Then, the disto-lingual canal (radix) was located easily without ultrasound or magnification and the canals were negotiated with C-Pilot \# 10 and \# 15 files (VDW Dental, Munich, Germany). Root canals were instrumented with a NiTi CM rotary system (Pro-T, MK Life, Porto Alegre, Brazil), with the DB up to an F3 (30.09) and the other root canals up to an F2 (25.08). The canals were copiously irrigated with $2.5 \%$ sodium hypochlorite (8 mL per channel) and a final rinse with 17\% EDTA for 3 min was performed before drying the canals with matched paper points \# 30 (VDW Dental, Munich, Germany). An intracanal dressing with calcium hydroxide paste (UltraCal XS, Ultradent) was applied for 15 days. During the second visit the intracanal dressing was removed with copious irrigation in the same way as in the first visit. After drying the canals with paper points \# 30, the MB, ML and DL were filled with gutta-percha by the lateral condensation technique, and the DB with the McSpadden technique and AH Plus sealer (Dentsply, Konstanz, Germany) (Figure 3D). The patient was referred for prosthetic rehabilitation.

Figure 3 - (A) Initial radiograph. (B) CBCT axial image. (C) CBCT coronal image. (D) Final radiograph in distoradial direction with "radix entomolaris" on left.

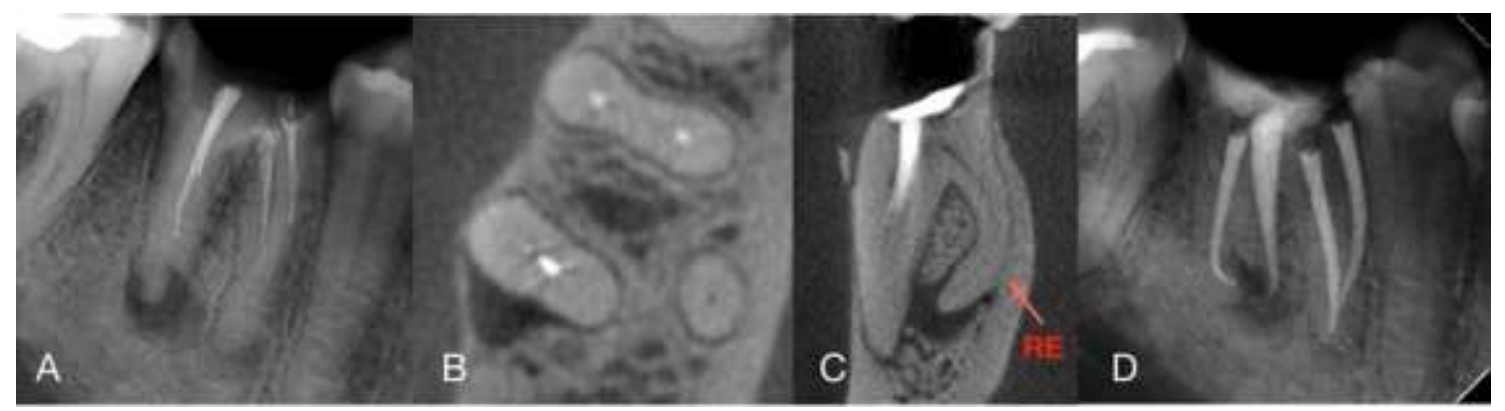

Source: Authors.

\section{Discussion}

The anatomy of root canal systems and the anatomical variations found in the different types of teeth provided information that might improve the outcome of endodontic treatment [Barletta et al. 2008]. Specifically, in the mandibular molars, the presence of an additional root is one of the anatomical variations that may be found; and when located in the distolingual region, it is called radix entomolaris [Calberson et al. 2007, Rodrigues, 2016, Souza, 2014]. Its prevalence, ranging between $24.5 \%$ to $33.3 \%$ [Tu et al. 2009, Kim, 2018], is strongly influenced by ethnicity, since it is more commonly found in individuals of Asian origin, as reported in Case 1. In a Caucasian population, such as the individuals in Cases 2 and 3, although this prevalence is low, it may occur in up to $4.2 \%$ of mandibular first molars [Ferraz et al. 1993]. In a more recent study using CBCT, Rodrigues et al. [16] found $2.58 \%$ of first mandibular molars that had distolingual roots (radix entomolaris) in a Brazilian population.

Entomolaris radix are generally shorter and thinner than other roots and may be separated or fused [Souza et al. 2014, Carlsen, 1990]. Wang et al. verified that $100 \%$ of the disto-buccal roots present a single root canal through the entire length of the radix, classified as Vertucci type I, in the same way as the 3 cases described in this article. However, other internal configurations can be found by means of computed microtomography, as demonstrated by Rodrigues et al., who found that although $96.36 \%$ of the entomolaris radix were type I, samples with Type V and type VII were also found. Souza-Flamini et al., also used microtomography and in a coronal section, found that these roots had a severe curvature in the buccal direction 
starting in the coronal third, corroborating the findings of reports in the literature [Chen et al. 2009, Gu, 2010] and those of the third case reported in this study (Figure 3C). De Moor et al. evaluated extracted human first molars and classified the morphologic features of the disto-lingual root into 3 types according to the pattern of their curvature; they showed that the radix entomolaris may also have a pronounced curve in the apical third of the root.

Walker and Quackenbush reported a 90\% precision in the diagnosis of 3-rooted mandibular molars using only panoramic radiographs. However, due to the fact that the RE is found mainly in the same bucco-lingual plane as that of the disto-buccal root, it may cause superimposition on the preoperative periapical or panoramic image [Souza et al. 2014]. This often results in inaccuracy when revealing this anatomic variation, but this problem can be minimized by performing angles of 20o [Vertucci et al. 1984], 25o [Wang et al.2011] and 30o [Calverson et al. 2007] in the mesial and distal directions on the periapical radiograph taken. Therefore, in the majority of cases these roots can be diagnosed by means of the initial periapical radiograph [Rozito et al. 2014, Poorni, 2018, Pradeep, 2018]. Nevertheless, it should be considered that the direction of radix curvature was mainly toward the buccal side, which cannot readily be detected in periapical radiographs [Kim et al. 2018]. Therefore, tomographic examination may be essential to detect the characteristics of the ER [López-Rosales et al. 2015]. CBCT images allow the identification of anatomic features and variations of the root canal system, in addition to clearly improving the detection of distolingual root configuration [Tu et al. 2009, Kim, 2018], so it could be considered a gold standard in the diagnosis and in providing help with the treatment of radix entomolaris.

In the third case reported, it was possible to observe the presence of the RE only by $\mathrm{CBCT}$, probably due to a superposition of the RE on the DB root or even due to the presence of significant bone thickness on the buccal surface (Figures $3 \mathrm{~B}$ and $3 \mathrm{C})$.

Generally mandibular molars with radix entomolaris have a trapezoidal spatial configuration of the canal orifices in the pulp chamber floor with a reported distance of $3.20 \mathrm{~mm}$ and $3.93 \mathrm{~mm}$ between the DB and DL canal orifices [Kim et al. 2018, Rodrigues, 2016, Souza, 2014]. An essential clinical approach to the location of and access to these root canals is to perform a slightly larger wear in the distal-lingual region [Calberson et al. 2007, Abella, 2011, Pradeep, 2018], resulting in changing a more triangular shape into a rectangular or trapezoidal shape [Calberson et al. 2007, Padmanabhan,2019], which can be seen in the image (Figure 2B) of the second case reported.

The presence of a dentin projection at the entrance to the RE root canals [Calberson et al. 2007, Souza, 2014] can make it difficult to locate this entrance when performing the access cavity. This projection can be more safely and conservatively be removed with the use of ultrasonic tips [López-Rosales et al. 2015], and the procedure may be optimized with the use of the magnification provided by an operating microscope. This concept of the association of technical resources was very well demonstrated in the case reports, as described in the presentation of the second case, in which it was possible to observe the RE in the initial radiograph (Figure 2A). However, as there was no success in locating it during the first visit, a CBCT was requested, which showed a dentin projection at the entrance of this canal (Figure 2B). During the second visit, a pear-shaped diamond ultrasonic tip was used to perform wear in the lingual direction, under an operating microscope (16x magnification), making it possible to locate and access the above-mentioned canal entrance. As regards magnification, loupes [Poorni et al. 2010] and microscopes [López-Rosales et al. 2015, Barletta, 2008, Souza, 2014] have been reported to be favorable resources for use in the identification and location of these root canals.

In cases of REs with abrupt curvatures, especially in the apical third, to avoid transportation during instrumentation and loss of working length, the use of automated NiTi instrument systems is recommended, as these allow for more centralized preparations and more conservative dilations [Calberson et al. 2007]. There is a report on root canal preparation with the NiTi rotating instrument \# 20.06 [Abella et al.2011], however studies with computed microtomography have shown that these roots can have a smaller diameter ranging from $0.19 \mathrm{~mm}$ to $0.25 \mathrm{~mm}$ and a larger diameter ranging from $0.29 \mathrm{~mm}$ to $0.35 \mathrm{~mm}$ 
[Rodrigues et al. 2016, Souza, 2014], in the region $1 \mathrm{~mm}$ short of the foraminal outlet, therefore, larger dilations would be recommended for adequate modeling on conclusion of preparation.

At present, the increase in apical dilation is possible with the use of instruments with heat treated NiTi alloys, as demonstrated in the cases reported here, in which instruments with a tip diameter close to $0.30 \mathrm{~mm}$ were used, which is therefore, in agreement with the larger diameters reported in anatomic studies.

\section{Conclusion}

Prior knowledge of the prevalence and morphological characteristics of possible anatomical variations of the radix entomolaris is extremely important for preoperative planning and effectively performing the endodontic intervention. Resources such as periapical radiography, CBCT, magnification with operative microscopy, the use of ultrasonic devices and NiTi instruments systems can be extremely valuable for the diagnosis and in the clinical approach to endodontic treatment of mandibular first molars with radix entomolaris.

\section{Conflict of interest}

No potential conflict of interest relevant to this article was reported.

\section{References}

Abella, F., Mercade, M., Duran-Sindreu, F., Roig, M. (2011). Managing severe curvature of radix entomolaris: three-dimensional analysis with cone beam computed tomography. Int Endod J; 44:876-885. doi: 10.1111/j.1365-2591.2011.01898.x

Barletta, F. B., Dotto, S. R., Reis, M. S., Ferreira, R., Travassos, R. M. C. (2008). Mandibular molar with five root canals. Aust Endod J 2008;34:129-132. doi: 10.1111/j.1747-4477.2007.00089.x

Calberson, F. L., De Moor, R. J., Deroose, C. A. (2007). The radix entomolaris and paramolaris: Clinical approach in endodontics. J Endod; 33:58-63. doi: 10.1016/j.joen.2006.05.007

Carabelli G. Systematisches handbuch der zahnheilkunde. 2nd ed. Vienna: Braumuller und Seidel; Vol.1844. p114.

Carlsen, O., Alexandersen, V. (1990). Radix entomolaris: Identification and morphology. Scand J Dent Res 1990;98:363-373. doi: 10.1111/j.16000722.1990.tb00986.x

Chen, G., Yao, H., Tong, C. (2009). Investigation of the root canal configuration of mandibular first molars in a Taiwan Chinese population. Int Endod J; 42:1044-1049. doi: 10.1111/j.1365-2591.2009.01619.x

Moor, R. J., Deroose, C. A., Calberson, F. L. (2004). The radix entomolaris in mandibular first molars: an endodontic challenge. Int Endod J; 37:789-799. doi: $10.1111 / \mathrm{j} .1365-2591.2004 .00870 . \mathrm{x}$

Ferraz, J. A., Pécora, J. D. (1993). Three-rooted mandibular molars in patients of Mongolian, Caucasian and Negro origin. Braz Dent J; 3:113-117. https://www.forp.usp.br/bdj/bdj3(2)/pdf/v3n2a07.pdf

Garg, A. K., Tewari, R. K., Kumar, A., Hashmi, S. H., Agarwal, N., Mishra, S. K. (2010).Prevalence of three-rooted mandibular permanent first molars among the Indian population. J Endod; 36:1302-1306. doi: 10.1016/j.joen.2010.04.019

Gu, Y., Lu, Q., Wang, P., Ni, L. (2010). Root canal morphology of permanent three-rooted mandibular first molars: Part II-measurement of root canal curvatures. J Endod; 36:1341-1346. doi: 10.1016/j.joen.2010.04.025

Kim, Y., Roh, B. D., Shin, Y., Kim, B. S., Choi, Y. L., Ha, A. (2018). Morphological characteristics and classification of mandibular first molars having 2 distal roots or canals: 3-dimensional biometric analysis using cone-beam computed tomography in a korean population. J Endod; 44:46-50. doi: 10.1016/j.joen.2017.08.005

López-Rosales, E., Castelo-Baz, P., De Moor, R., Ruíz-Piñón, M., Martín-Biedma, B., Varela-Patiño, P. (2015). Unusual root morphology in second mandibular molar with a radix entomolaris, and comparison between cone-beam computed tomography and digital periapical radiography: a case report. $\mathrm{J}$ Med Case Rep 2015;9:2-6. doi: 10.1186/s13256-015-0681-x

Oliveira, P. de A. C.; Franco, A.; Oliveira, L. B..; Souza Lima, C. A.; Junqueira, J. L. C. .; Cavalette, M. R. M. L. .; Oenning, A. C. C. . (2021). Cone-beam computed tomography in Endodontics: an exploratory research of the main clinical applications. Research, Society and Development, [S. 1.], v. 10, n. 1, p. e42910111842, 2021. doi: 10.33448/rsd-v10i1.11842.

Padmanabhan, K. (2019). Endodontic management of radix entomolaris and pulp stone in mandibular first molar of 25 mm length - case report. Int J Dentistry Res; 4:40-42. 
Research, Society and Development, v. 10, n. 15, e219101522706, 2021

(CC BY 4.0) | ISSN 2525-3409 | DOI: http://dx.doi.org/10.33448/rsd-v10i15.22706

Poorni, S., Senthilkumar, A., Indira, R. (2010). Radix entomolaris in mandibular molars confirmed using spiral CT: a case report. Endo (Lond Engl); 4:1-5. Pradeep P, Nayak G, Arya N. (2018). Treating mandibular molars with extra roots - Radix entomolaris. J Dent Maxillofacial Res 2018;1:13-16. doi: $10.30881 /$ jdsomr.00005

Rodrigues, C. T., Oliveira-Santos, C., Bernardineli, N., Duarte, M. A., Bramante, C. M., Minotti-Bonfante, P. G., Ordinola-Zapata, R. (2016). Prevalence and morphometric analysis of three-rooted mandibular first molars in a Brazilian subpopulation. J Appl Oral Sci; 24:535-542. doi: 10.1590/1678-775720150511

Rozito, T. K., Piskorz, M. J., Rozito-Kalinowska, I. K. (2014). Radiographic appearance and clinical implications of the presence of radix entomolaris and radix paramolaris. Folia Morphol; 73:449-454. doi: 10.5603/FM.2014.0067

Song, J. S., Choi, H. J., Jung, I. Y., Jung, H. S., Kim, S. O. (2010). The prevalence and morphologic classification of distolingual roots in the mandibular molars in a Korean population. J Endod; 36:653-657. doi: 10.1016/j.joen.2009.10.007

Souza-Flamini, L. E., Leoni, G. B., Chaves, J. F. M., Versiani, M. A., Cruz-Filho, A. M., Pécora, J. D., Souza-Neto, M. D. (2014). The radix entomolaris and paramolaris: a micro-computed tomographic study of 3-rooted mandibular first molars. J Endod; 40:1616-1621. doi: 10.1016/j.joen.2014.03.012

Sperber, G. H., Moreau, J. L. (1998). Study of the number of roots and canals in Senegalese first permanent mandibular molars. Int Endod J; 31:112-116. doi: 10.1046/j.1365-2591.1998.00126.x

Tu, M. G., Huang, H. L., Hsue, S. S., Hsu, J. T., Chen, S. Y., Jou, M. J., Tsai, C. C. (2009). Detection of permanent three-rooted mandibular first molars by cone-beam computed tomography imaging in Taiwanese individuals. J Endod; 35:503-507. doi: 10.1016/j.joen.2008.12.013

Vertucci, F. J. (1984). Root canal anatomy of the human permanent teeth. Oral surg Oral Med Oral Pathol; 58: 589-599. doi:10.1016/0030-4220(84)90085-9 Walker T, Quakenbush LE. (1985). Three rooted lower first permanent molars in Hong Kong Chinese. Br Dent J; 159:298-289. doi: 10.1038/sj.bdj.4805710

Wang, Q., Yu, G., Zhou, X-d, Peters, O. A., Zheng, Q-h., Huang, D-m. (2011). Evaluation of X-ray projection angulation for successful radix entomolaris diagnosis in mandibular first molars in vitro. J Endod; 37:1063-1068. doi: 10.1016/j.joen.2011.05.017

Wang, Y., Zheng, Q. H., Zhou, X. D., Tang, L., Wang, Q., Zheng, G. N., Huang, D. M. (2010). Evaluation of the root and canal morphology of mandibular first permanent molars in a western Chinese population by cone-beam computed tomography. J Endod; 36:1786-1789. doi: 10.1016/j.joen.2010.08.016 